\title{
POLICY EVALUATION OF REGIONAL EXPANSION AND DETERMINATION REGIONAL BOUNDARIES IN BANTEN AND WEST JAVA PROVINCE
}

\author{
Romi Saputra \\ Study Program of Population and Civil Registration, Institut Pemerintahan Dalam Negeri (IPDN), Indonesia, \\ Jl. Raya Bandung-Sumedang KM. 21 Jatinangor, 456363 \\ E-mail: romisaputra@ipdn.ac.id
}

\begin{abstract}
The regional expansion is a way to accelerate development acceleration. In addition, regional expansion is the process of dividing an existing administrative area into two or more new autonomous regions. Regional expansion in Indonesia is carried out based on the Law of the Republic of Indonesia number 9 of 2015 concerning Regional Autonomy and Regional Government as a result of the second amendment to the Law of the Republic of Indonesia Number 23 of 2014. However, in the process of regional expansion in Indonesia, there are still some problems. Therefore, this study aims to evaluate government policies in regional expansion and determine regional boundaries in the provinces of Banten and West Java based on the laws in force in Indonesia. The method used in this research is the mix method, namely quantitative and qualitative. The data used are obtained from references and interviews related to regional autonomy policies, regional governments, and the determination of regional boundaries. The results of the evaluation, there are several factors that cause regional expansion, namely religious differences, ethnic and cultural differences, inequality in economic development in an area, and the size of the area. The formation of regional boundaries is carried out through 4 stages, namely Allocation, Delimitation, Demarcation, and Administration. One very important aspect of the implementation of regional autonomy is to merge regions with the hope of strengthening the relationship between local governments and local communities. In addition, it is hoped that there will be more intensive interaction between the community and the new local government, civil society will get better rights and obligations as citizens.
\end{abstract}

Key words: Autonomous Region; spatial conflict; regional expansion; decentralization

\section{EVALUASI KEBIJAKAN PEMEKARAN DAERAH DAN PENENTUAN BATAS DAERAH DI PROVINSI BANTEN DAN JAWA BARAT}

\begin{abstract}
ABSTRAK. Pemekaran daerah merupakan salah satu cara untuk mempercepat akselerasi pembangunan. Selain itu, pemekaran daerah adalah proses pembagian wilayah administrasi yang ada menjadi dua atau lebih daerah otonom baru. Pemekaran daerah di Indonesia dilakukan berdasarkan UU RI Nomor 9 Tahun 2015 tentang Otonomi Daerah dan Pemerintahan Daerah sebagai hasil perubahan kedua atas UU RI Nomor 23 Tahun 2014. Namun, dalam proses pemekaran daerah di Indonesia, masih terdapat beberapa permasalahan. Oleh karena itu, penelitian ini bertujuan untuk mengevaluasi kebijakan pemerintah dalam pemekaran daerah dan menentukan batas wilayah di Provinsi Banten dan Jawa Barat berdasarkan peraturan perundang-undangan yang berlaku di Indonesia. Metode yang digunakan dalam penelitian ini adalah metode campuran, yaitu kuantitatif dan kualitatif. Data yang digunakan diperoleh dari referensi dan wawancara terkait kebijakan otonomi daerah, pemerintah daerah, dan penetapan batas wilayah. Hasil evaluasi, terdapat beberapa faktor penyebab pemekaran wilayah yaitu perbedaan agama, perbedaan suku dan budaya, ketimpangan pembangunan ekonomi di suatu wilayah, dan luas wilayah. Pembentukan batas wilayah dilakukan melalui 4 tahapan, yaitu allocation, delimitation, demarcation, dan administration. Salah satu aspek yang sangat penting dari pelaksanaan otonomi daerah adalah penggabungan daerah dengan harapan dapat mempererat hubungan antara pemerintah daerah dengan masyarakat setempat. Selain itu, diharapkan dengan adanya interaksi yang lebih intensif antara masyarakat dengan pemerintah daerah yang baru, masyarakat sipil akan mendapatkan hak dan kewajiban yang lebih baik sebagai warga negara.
\end{abstract}

Kata kunci: Daerah otonom; konflik spasial; pemekaran daerah; desentralisasi

\section{INTRODUCTION}

Regional expansion is a process of dividing an existing administrative region (autonomous region) into two or more new autonomous regions based on Republic of Indonesia Law Number 9 of 2015 concerning Regional Autonomy and Regional Government as a result of the second amendment to the Law of the Republic of Indonesia Number 23 of 2014 (Fadhilah, 2016). Its implementation is based on Government Regulation Number 78 of
2007. Meanwhile, spatial conflict is the potential for territorial conflicts that arise as a result of a boundary dividing one area into two different areas (Kamim et al., 2018).

The determination of regional boundaries in Indonesia has been carried out since Indonesia's independence in 1945. For the purposes of state management, Indonesia is divided into provincial areas. Provincial areas divided into regencies and cities, each of which has a regional government. However, this division of regions is still more 
administrative in nature because the government system is still centralized. Since the collapse of the New Order era in 1998, the Reform Era was born. In the Reformation Era, Law Number 22 of 1999 concerning Regional Government or better known as the Regional Autonomy Law was born which was later revised to Law Number 9 of 2015 concerning Regional Autonomy and Regional Government as a result of the second amendment to the Law of the Republic of Indonesia Number 23 of 2014 (Ristanti and Handoyo, 2017; Akbal, 2017; Rustandi, 2017). In line with the spirit of regional autonomy, since 2000, many new regions were established, both in provinces and districts / cities (Rachayu, 2019; Afandi, 2013).

The division of the region into several regions results in changes to regional boundaries both administrative and spatially. Expansion, which is more meaningful as a regional solution, always raises problems in determining territorial boundaries. Since the era of regional autonomy, the number of border dispute cases between regions includes 17 problems involving 19 provinces and 50 problems involving 81 districts/ cities (Sahyana, 2019). In 1945, Stephen B. Jones wrote a theory about boundary making. In this theory, the main stages in determining territorial boundaries are explained, namely: allocation, delimitation, demarcation, and administration of boundaries (Moore and Woodrow, 2010; Rusli, 2003). His writing will discuss Boundary Making Theory in determining regional boundaries in Indonesia. Furthermore, in this case, we will look at the problems of regional boundary disputes in Indonesia that emerged during the era of regional autonomy and identify the causes of existing territorial boundary disputes using the conflict circle theory approach, C.W. Moore (1987).

Article 11 ofLawno. 43 of 2008 states: paragraph (1) In the management of State Territories and Border Areas, the provincial government is authorized: (a) to implement government policies and determine other policies in the context of regional autonomy and assistance tasks; (b) coordinating development in the Border Area; (c) developing Border Areas between regional governments and / or between local governments and third parties; and (d) supervise the implementation of Border Area development carried out by district / city governments. paragraph (2) In the context of implementing the provisions referred to in paragraph (1), the provincial government is obliged to determine the costs for the development of the Border Area (Zein, 2016; Mangku, 2017).

Article 12 paragraph (1) In the management of State Territory and Border Area, the district / city government is authorized: (a) to implement government policies and stipulate other policies in the context of regional autonomy and assistance tasks; (b) safeguarding and maintaining boundary markers; (c) carry out coordination in the framework of implementing development tasks in the Border Area in its territory; and (d) developing Border Areas between regional governments and / or between local governments and third parties. (2) In the framework of implementing the provisions referred to in paragraph (1), the district / city government is obliged to determine the costs for the development of the Border Area (Zein, 2016; Mangku, 2017).

Institutionally, the regional government is given the authority to form institutions that handle border areas, as regulated in Article 13 of Law no. 43 of 2008: The exercise of authority as referred to in Article 10, Article 11, and Article 12 shall be further regulated by a Government Regulation. Institutional Chapter Article 14 paragraph (1) To manage State Borders and manage Border Areas at the central and regional levels, the government and regional governments form a National Management Agency and Regional Management Agency paragraph (2). The Management Body as referred to in paragraph (1) is led by a head of an agency who is accountable to the President or a regional head in accordance with their authority. paragraph (3) Membership of the Management Body comes from elements of the government and regional governments related to the borders of the State Territory(Zein, 2016; Mangku, 2017).

Article 15 paragraph (1) The Management Body has the duties: (a) to determine the policy for border development programs; (b) determine the budget requirements plan; (c) coordinate implementation; and (d) carry out evaluation and supervision. Paragraph (2) The technical agency for development is carried out by a technical agency in accordance with its main tasks and functions. Article 16, The working relationship between the National Management Agency and the Regional Management Agency is a coordinative relationship. Article 17, in carrying out its duties, the Management Body is assisted by a permanent secretariat domiciled in the ministry whose duties and responsibilities are in the field of domestic government. Article 18 paragraph (1) Further provisions regarding the position, duties, functions and organizational structure as well as the work procedures of the Managing Agency and permanent secretariat at the central level are regulated by a Presidential Regulation. Paragraph (2) Further provisions regarding the position, duties, functions and organizational structure as well as the work 
procedures of the Border Management Agency(Zein, 2016; Mangku, 2017).

Based on the formal legal construction above, structurally, the "legal umbrella" of the Border Area has a strong legal basis both in Law no. 9 of 2015 and Law no. 43 of 2008, only juridical in its implementation, there are still problems in determining the border area, as a special area it must be determined by law, and Law no. 43 of 2008 can be a legal basis during the transitional period, only the problem remains waiting for the Government Regulation which provides a reference for the implementation of the two laws, especially in relation to the Border Area as a Special Zone, although on the other hand the regional government can propose the Border Area to be a special area, but this permanent mechanism is regulated by a Government Regulation, what can be done at this time is to form a Border Area Management Agency regarding the position, duties, functions and organizational structure, as well as the work procedures of the Management Agency at the regional level regulated by regional regulations, this too must be 'stressing'. the acceleration of the drafting of regional regulations and must also be considered and must refer to the Presidential Regulation which regulates the National Management Agency for the management border area, which is regulated at the regional level by regional regulations (Kushandayani, 2011; Sulistiowati, 2014; Hamid, 2018).

Based on the description above, this study intends to evaluate government policies in regional expansion and determine regional boundaries for local governments in Banten Province and West Java Province based on applicable regulations in Indonesia. This needs to be done in the affirmation of regional boundaries as an effort to create clear and definite boundaries both from the juridical and physical aspects in the field based on the applicable rules. In practice it can be determined precisely the location and position of the boundary of an area in the field to the determination of the coordinates of the boundary on the map.

\section{METHOD}

Analysis of data obtained, both primary and secondary data, is carried out to understand various problems or issues related to understanding the concept of national insight, especially local government officials and communities in border areas, the analysis is an assessment of various circumstances and situations carried out based on principles, approaches and methods. and scientific and practical analytical techniques. Primary and secondary data are processed and analyzed with various factors related to internal problems related to understanding the concept of national insight on the object in question. The approach used to perform quantitative and qualitative data analysis through:

1. Survey method (Mathiyazhagan and Nandan, 2010)

2. Content Analysis or document study (Vaismoradi et al., 2013).

The design method used in this research is the mix method. Mix method is a research approach that combines or combines qualitative and quantitative forms (Ghasempour et al., 2014; Rohmahwati, 2016). According to Teddlie and Tashakkori (2011), mix method research is a combination of quantitative and qualitative research methods. The combination or amalgamation of quantitative and qualitative research methods is used together in a study in order to obtain more comprehensive, valid, reliable and objective data. Based on the data obtained, an evaluation of administrative government policies and the determination of regional boundaries for local governments in the provinces of Banten and West Java was carried out.

Evaluation is the most important policy process because with evaluation we can assess the extent to which needs, values and opportunities through public action, where certain goals can be achieved. So that the appropriateness of policies can be ascertained by new policy alternatives or revised policies (Melawi, 2014; Rothenberg et al., 2017). The evaluation characteristics consist of four characters. The first is the focus on value, because evaluation is an assessment of a policy in the accuracy of achieving policy goals and objectives. Second is the fact-value interdependence, because to determine the value of a policy is not only seen from the level of performance but also seen from the evidence or the fact that the policy can solve certain problems. The third is the present and past orientation, because evaluative demands are directed at present and past results so that the evaluation results can be compared to the value of the policy. The fourth is the duality of values, because the values of the evaluation have a double meaning, both recommendations as far as the existing values and the values required to influence the achievement of other goals. Evaluating a program or public policy requires a criterion to measure the success of the public program or policy. Regarding the performance of policies in producing information, there are evaluation criteria (Oktarina, 2018). 


\section{RESULTS AND DISCUSSION}

The purpose of affirming regional boundaries is to create clear and definite regional boundaries both from the juridical and physical aspects in the field. Regional boundaries determine the area for exercising the authority of one region with another. So the unclear and definite boundaries also result in a blurred boundary of exercising the authority of one region with another. The area that is still disputed in the confirmation of the boundaries of these two areas covers an area of \pm 262 hectares. The area is mostly in the form of rice fields, while others are residential areas and offices.

In the previous discussion, it has been described that changes in regional borders in real terms began in 1975 as a result of the conflict in the Bulurejo Village Head Election. This means that it occurred during the enactment of Law Number 5 of 1974 concerning the Principles of Government in the Regions. Article 4 paragraph (3) of Law Number 5 of 1974 regulates changes in boundaries that do not result in the deletion of an area, changes in regional names, as well as changes in names and relocation of its capital are stipulated by Government Regulation (PP). In fact, that the changes in regional boundaries that have occurred until now have only been accommodated on the City Administration Map, there has been no legal formal confirmation of boundaries.

Impact in the Implementation of Building Construction Permit Services (IMB)

Building construction permits are required for building arrangements to conform to the Regional Spatial Plan. However, the social impact that is not so broad due to unfinished boundary affirmations occurs in IMB services and occurs only in cases of buildings that are split by regional boundaries.

\section{Dispute Resolution}

If there is a boundary dispute, the settlement of the dispute over regional boundaries is in accordance with Law no. 9 of 2015 Article 198, is:

1. In the event of a dispute in the implementation of government functions between regencies / cities in one province, the Governor shall resolve the dispute.

2. In case of disputes between provinces, between provinces and districts / cities in their territory, as well as between provinces and districts / cities outside their territory, the Minister of Home Affairs shall resolve the dispute.

3. The decisions as referred to in paragraph (1) and paragraph (2) are final.
Completion Target of 609 Inter-Regional Boundary Segments, includes:

1. Inter-Provincial Boundaries Numbering 127 Boundary Segments

2. Boundaries between districts / cities in one province totaling 482 boundary segments.

3. Inter-Provincial Boundaries Become the Authority of the Minister of Home Affairs to Resolve them.

4. The Inter-District / City Boundary Within 1 Province is the Authority of the Governor to Resolve It

5. The Legal Basis for Settlement Is In Law No. 32 of 2004 Article 198 and Minister of Home Affairs Regulation No. 1 of 2006 Article 20

6. Of the 482 Boundary Segments Covering All 33 Provinces.

\section{Expedited Boundary Dispute Resolution}

The Directorate General of Public Affairs is currently initiating new efforts to accelerate the settlement of inter-regional boundary disputes which are taken through the regulatory route of the revision of the Minister of Home Affairs Regulation No.1 / 2006 and the method of boundary dispute resolution itself and added by strengthening and optimizing existing performance. Thus, there are several things that are mainly pointed in this acceleration, which include:

1. Revised Minister of Home Affairs Regulation No.1 of 2006 concerning Affirmation of Boundaries in the Field.

2. Optimizing Boundary Resolution by Kartometric method by avoiding as far as possible field tracking. This can be optimized if there is data support from the Government (in the form of a base map, a more accurate Indicative Boundary map by utilizing the best available data such as satellite imagery, SRTM, DEM and IFSAR (in digital form). Cooperation (Agreement or Cooperation Contract) with Bakosurtanal and Dittopad for the provision of Topographic or Topographic Base Maps in digital format with an adequate scale.

3. The cartographic method is carried out at the tracing phase of regional boundaries with a note that for tracking boundaries that are difficult to do in the field, traced on a working map and the coordinate points are determined and the boundary coordinate points that have not been agreed upon / are still doubtful, can be traced / rechecked to the field. The results of the tracking on the agreed map are used as material for the preparation of the Minister of Home Affairs Regulation on Regional Boundaries; Pillars can be installed later if deemed necessary and possible. 


\section{General Condition of Tangerang Regency}

Astronomically, Tangerang Regency is located in the eastern part of Banten Province at the coordinates of $106^{\circ} 20$ ' $106^{\circ} 43^{\prime}$ East Longitude and $6^{\circ} 00^{\prime}$ $6^{\circ} 20^{\prime}$ South Latitude. Topographically, Tangerang Regency is located in the lowland and highland areas. The lowlands are mostly located in the northern region, namely Teluknaga, Mauk, Kemiri, Sukadiri, Kresek, Kronjo, Pakuhaji, and Sepatan Districts. Meanwhile, the highlands are located in the central region towards the south. Administratively, Tangerang Regency consists of 29 sub-districts, 28 sub-districts and 246 villages.

Geographically, the area of Tangerang Regency is $959.6 \mathrm{~km} 2$ or $9.93 \%$ of the total area of Banten Province, with the northern borders bordering the Java Sea, the eastern borders with South Tangerang City and Tangerang City, in the south bordering Bogor Regency and the City. Depok, while the west is bordered by Serang and Lebak Regencies. The map of the Tangerang Regency area is given in Figure 1.

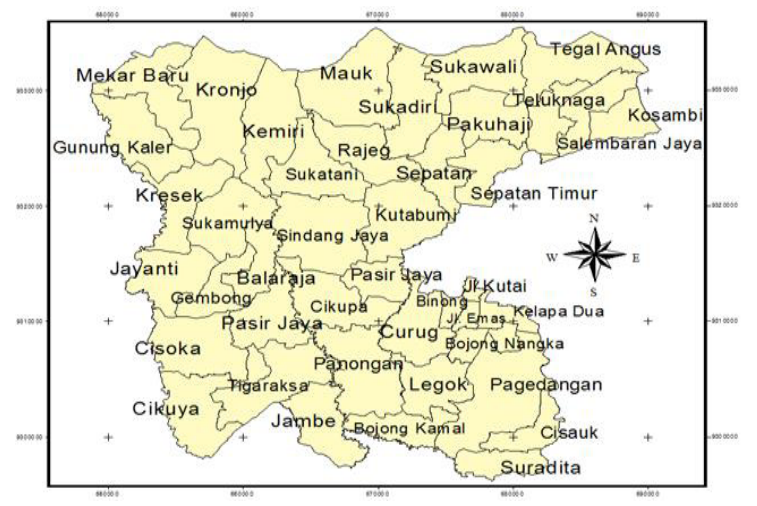

Figure 1. Map of Tangerang Regency

\section{General Condition of Tangerang City}

Astronomically the location of Tangerang City Graphically, Tangerang City is located at positions 10636 - 10642 East Longitude (BT) and 66 - 6 South Latitude (LS). The north is bordered by Teluk Naga Subdistrict and Sepatan Subdistrict, Tangerang Regency, to the south is Curug Subdistrict, Serpong Subdistrict with DKI Jakarta, while the West is bordered by Cikupa Subdistrict, Tangerang Regency.

Administratively, the area of Tangerang City is divided into 13 districts, namely Ciledug $(8,769 \mathrm{Km} 2)$, Larangan $\left(9,611 \mathrm{Km}^{2}\right)$, Karang Tengah $\left(10,474 \mathrm{Km}^{2}\right)$, Cipondoh ((17.91 Km2), Pinang $\left(21.59 \mathrm{Km}^{2}\right)$, Tangerang $\left(15,785 \mathrm{Km}^{2}\right)$, Karawaci $\left(13,475 \mathrm{Km}^{2}\right)$, Jatiuwung $\left(14,406 \mathrm{Km}^{2}\right)$, Cibodas $\left(9,611 \mathrm{Km}^{2}\right)$, Pot $\left(9,543 \mathrm{Km}^{2}\right)$, Batuceper $\left(11,583 \mathrm{Km}^{2}\right)$, Neglasari $\left(16,077 \mathrm{Km}^{2}\right)$, and Benda $\left(5,919 \mathrm{Km}^{2}\right)$, covering 104 sub-districts with 981 neighborhood units (RW) and 4,900 neighborhood units (RT). The general condition map of Tangerang City is given in Figure 2.

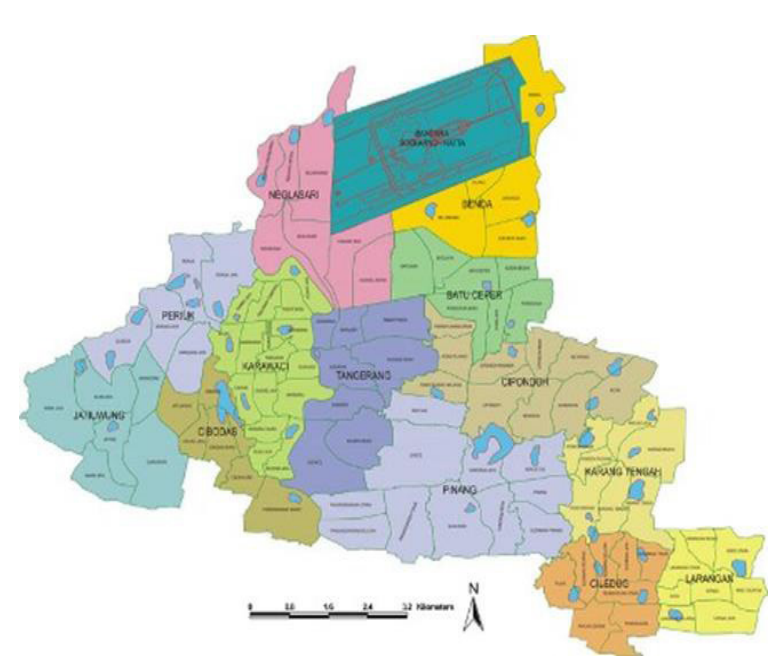

Figure 2. General Condition of Tangerang City

\section{Conflict Triggers}

The conflict trigger factors referred to here are the direct factors that cause a more open dispute or action or reaction from the parties to the conflict.

The antagonism related to the regional boundary between Magelang Regency and Magelang City first appeared due to structural factors, namely because of the Ministry of Home Affairs policy on the plan to expand the area of Magelang City in the context of changing the territorial boundaries that determined that Mertoyudan, Banyurojo and Bulurejo Villages were completely transferred to the Magelang City area. Starting from this incident, the resolution of the problem of regional boundaries, especially in relation to the villages of Bulurejo, Banyurojo and Mertoyudan, has become a sensitive issue and has the potential to cause antagonism (latent conflict).

In the context of affirming regional boundaries, what can be categorized as a trigger for conflict is an interest factor in the form of an interest in existence area. Because of this interest, there was an action by the Magelang City Government in an effort to defend its area by trying to increase the area to the Magelang Regency area. However, on the other hand, this action received a reaction from Magelang Regency which still maintains its territorial integrity.

\section{Expansion in Building The Region}

Regional expansion is expected to create regional independence. The purpose of expansion as stated in various laws and regulations should be aimed at improving the welfare of the community through:

1. Improved services to the community,

2. Acceleration of growth of democratic life,

3. Acceleration of the implementation of regional economic development,

4. Acceleration of regional potential management,

5. Increasing security and order, 
6. Increasing harmonious relations between the center and the regions.

Regional development is intended to reduce the growth gap and inequality between regions. In the national context, the existence of inter-regional development causes the achievement of the overall national development goals not to be achieved.

In the context of regional development, an approach based on economic concepts is the most widely used. The aim of this concept is development in key sectors, in specific locations, thus leading to progress throughout the region. There are several concepts of regional development, which are:

1. Encouraging regional deconcentration, where this concept aims to reduce the level of regional concentration and to form an appropriate spatial structure, especially in some parts of nonmetropolitan areas.

2. Reviving underdeveloped regions as regions characterized by high unemployment, low per capita income, and low levels of community service facilities.

3. Modifying the city system, as a controller of urbanization towards growth centers, that is, with the arrangement of the urban system, it has a wellstructured hierarchy. This is expected to reduce population migration to big cities.

4. Achievement of regional balance. This occurs as a result of the unsatisfactory inter-regional economic structure, which usually takes into account the level of welfare and is related to the unutilized use of natural resources in several regions.

The division of districts / cities into new districts / cities is basically an effort to improve the quality and intensity of services to the community. In terms of regional development, the new district / city candidates that will be formed need to have a resource base that is balanced from one another. This needs to be done so that there are no striking disparities in the future. Furthermore, in an effort to expand the territory a new public space will be created which is the collective need of all citizens of the new territory. This new public space will affect the activities of a person or society so that they will feel benefited because of their maximum service.

Finally, the expansion of this region aims to improve the welfare of the people, increase resources in a sustainable manner, increase the harmony of developments between regions and between sectors, strengthen national integration which as a whole can improve the quality of life.

However, regional formation can only be carried out if it meets the administrative, technical and physical requirements of the region. For provinces, the administrative requirements that must be fulfilled include the approval of the district/ city Regional People's Representative Assembly (DPRD) and regents / mayors which will become the scope of the province concerned, the approval of the main provincial DPRD and the governor, as well as a recommendation from the Minister of Home Affairs. Meanwhile, for districts / cities, administrative requirements that must also be met include the approval of the district / city DPRD and the regent / mayor concerned, the approval of the provincial DPRD and the governor, as well as a recommendation from the Minister of Home Affairs.

There are several factors that can trigger regional expansion, including:

\section{$>$ Religious differences}

The reality that occurs in society shows that religious differences are one of the elements that can cause the desire of the community to separate themselves from an existing country / region to become a new country / region.

\section{$>$ Ethnic and cultural differences}

As with religious differences, ethnic and cultural differences are also other important elements that can trigger the desire to expand territories. The reality shows that people feel less comfortable when living in a society with different ethnicities, customs and habits. If this cultural unity is disrupted due to the presence of members of other communities with different cultures, there is often tension and even social conflict in that community.

$>$ Inequality in economic development between regions

The next aspect that tends to trigger regional expansion is the imbalance of economic development between regions. Also included in this aspect is the imbalance in the availability of high-value natural resources, such as oil, natural gas and coal, which in turn will encourage inequality in prosperity between regions. This imbalance in turn encourages social jealousy and the feeling of being 'ignored' by the central government so that finally the desire to expand the region arises. Indications of the occurrence of inequality in development between regions can be seen by calculating the data on GRDP per capita and population as the main indicators through the Williamson Index.

$>$ Area

The size of the area can also trigger the desire to expand the territory. The reason is because a large area will tend to prevent public services from being carried out effectively and evenly to all remote areas. Meanwhile, the duty of local 
government is to provide public services to all people in the region. In order to improve services to the community, one way that can be taken is by expanding the region.

Furthermore, it is recommended that the technical requirements for the formation of a new region must cover the factors that form the basis for the formation of the region which include the following factors:

1. Economic capability, is a reflection of the results of economic business activities taking place in a province, district / city, which can be measured from the Gross Regional Domestic Product (GRDP) and regional revenues themselves.

2. Regional potential is a reflection of the availability of resources that can be utilized and the welfare of the community which can be measured from financial institutions, economic facilities, educational facilities, health facilities, transportation and communication facilities, tourism facilities and employment.

3. Socio-culture, is a reflection related to the social structure and cultural patterns of the community, the social conditions of the community which can be measured from places of worship, places for activities of social and cultural institutions, and sports facilities.

4. Socio-politics, is a reflection of the socio-political conditions of society which can be measured from the participation of the community in politics and social organizations.

5. Population, is the total population of an area.

6. Area, is a certain area of an area.

7. Defense and security

8. Other factors that enable the implementation of regional autonomy.

Other factors that are intended must include at least 5 districts / cities for the formation of provinces, and at least 5 sub-districts for the formation of districts, and 4 sub-districts for the formation of cities, the location of the prospective capital city, government facilities and infrastructure.

\section{Preparation area}

In carrying out regional expansion, the formation of a preparatory area is important in efforts to organize the region. In line with this, the role of the preparatory regions does not only cover administrative matters, but also needs to cover several other aspects, including: a. Prepare physical requirements related to spatial planning and boundaries. Apart from that, documents for the spatial plan of the location of the candidates for the capital of the new autonomous region and the candidates for the capital of the main region are also formulated.

Prepareinstitutionalandorganizationalrequirements related to office requirements, identification of assets, staff functions, organizational structure, and planning and budgeting processes. This is important in the preparation period so that the process of regional expansion becomes a shared need between the Main Region and the New Autonomous Region Candidates. Thus, conflicts over the transfer of assets can be avoided from the start.

Prepare technical administrative requirements relating to cooperation with the Main Region and third parties that will conduct studies on the feasibility of establishing a new autonomous region or regional expansion. With regard to this preparatory area, it is necessary to have special requirements, such as a region thathas mettechnical and administrative feasibility standards for the formation of a new autonomous region which is determined through a recommendation from the DPOD or Minister of Home Affairs Regulation which then prepares itself for a minimum of 2 (two) years as a period. preparations before being passed as a new autonomous region stipulated by law.

\section{Role of Society}

The voice and role of the community are the main requirements for the sustainability of a process of regional expansion. This is in accordance with the nature of regional expansion. After understanding the factors that cause conflict (and also the resulting impacts) and the problems that occur, recommendations for problem solving can be formulated as follows: (1) Each party needs to evaluate efforts to realize an agreement in confirming boundaries. areas that are being implemented and have yet to produce satisfactory results. The evaluation referred to is a serious and comprehensive evaluation of the implementation of the Agreement on the Implementation of Boundary Emphasis.

The evaluation starts with the internal correction of each organization which includes the evaluation of the performance of the "executor" of regional boundary affirmation activities, so that the followup of the evaluation is expected to eliminate the accelerating factors that occur at the implementing technical level. Thus, it can be realized: (1) The formulation and presentation of studies or data that are free from the content of interests that tend to direct policies that are solely pursuing one- 
sided gain, (2) There is no impression of negative behavior by other parties such as imposing their will in coordination process and the existence of behavior that tends to be "money oriented", (3) Competent human resources so as to avoid imbalance in the professionalism of human resources between the two parties which causes differences in the data used and differences in arguments regarding the level of data relevance, (4) This need to create a de-escalation of money conflicts has been caused by accelerating factors among influential people and activists.

In this case, it should be noted that a structural approach can cause conflict, so it is necessary to avoid decisions that can increase the aspirations of one or both parties. Each party should prepare itself for conciliation by taking into account three factors: (1) Both parties must acknowledge the reality and situation of the conflict that occurred between them, (2) The struggling interests must be neatly organized, not divided and divided. -box so that each party clearly understands the scope of the other party's demands, (3) The two parties agree on the rules of the game which are the basis and reference in the relationship and interaction between them, (4) Conciliation is carried out in all manner parties discuss and debate openly and deeply to reach an agreement without any parties monopolizing the conversation or imposing their will, (5) Increasing the support of political elites based on the spirit of unity and integrity within the framework of the Republic of Indonesia which at that time was able to jointly pay attention to obstacles which is faced by the City of Magelang, especially in order to overcome urban population density. This means that political elites need to realize that in the interests of the wider community, sometimes certain interests need to be negotiated.

\section{CONCLUSION}

Based on the results and discussion above, it can be concluded that one aspect of the implementation of regional autonomy is related to the expansion and merging of regions in the hope of strengthening the relationship between local governments and local communities in an effort to live a democratic life. This is done as an effort by the government to provide better rights and obligations for civil society as citizens. Therefore, the government in determining regional autonomy makes a rule contained in Law Number 24 of 1992 concerning Spatial Planning, the area is a unitary geographical space and all elements related to the boundaries of the system are determined based on administrative and/or functional aspects. There are several reasons for the formation of Banten Province, namely historical, ethnic, economic, area and population factors. The historical factor is influenced by the conflict between the Sunda Kingdom and the Banten Sultanate where at that time there was an attack on the Banten Sultanate to Padjajaran in 1575 which in the Banten invasion of Padjajaran occurred in three major waves. Because of these historical factors, the people of Banten feel that they have their own history that is different from Sundanese, in this case the province of West Java. The ethnic factor is another reason for the Banten people to form the province of Banten, this is based on the fact that the people of Banten feel that there is ethnic discrimination in strategic positions in the ranks of government bureaucracies in the Banten area and in the provincial government. In addition, the economic factor is an issue raised by the people of Banten to expand from the province of West Java. The people of Banten feel that the process of economic, educational and social development that takes place in Banten is slower than other areas in West Java. On the other hand, the West Java provincial government does not agree with the establishment of Banten Province due to the reduced amount of Regional Original Revenue. This is based on the fact that Banten is one of the regions with the largest contributor to regional income for the province of West Java. In addition, with the establishment of the province of Banten, the area of West Java will decrease and the population will also decrease. This can have an impact on the amount of regional income in the province of West Java which will decrease.

\section{REFERENCES}

Afandi, M.N. (2013). Peluang Dan Tantangan pembangunan Daerah Otonom Baru Di Indonesia (Studi Kasus Kabupaten Pangandaran Provinsi Jawa Barat). Jurnal Ilmu Administrasi: Media Pengembangan Ilmu dan Praktek Administrasi, 10(2), 275-296.

Akbal, M. (2017). Harmonisasi Kewenangan Antara Pemerintah Pusat Dan Daerah Dalam Penyelenggaraan Otonomi Daerah. SUPREMASI: Jurnal Pemikiran, Penelitian Ilmu-Ilmu Sosial, Hukum Dan Pengajarannya, 11(2), 99-107.

Fadhilah, N.L. (2016). Implikasi Pemberlakuan Undang-Undang No. 9 Tahun 2015 tentang Perubahan Kedua Undang-Undang No. 23 Tahun 2014 tentang Pemerintah Daerah atas Perizinan Pertambangan Terhadap Legislasi di 
Daerah. Jurnal Ilmiah Pendidikan Pancasila dan Kewarganegaraan, 1(2), 91-101.

Ghasempour, Z., Bakar, M.N. \& Jahanshahloo, G. R. (2014). Mix-method design in educational research: Strengths and challenges. International Journal of Pedagogical Innovations, 2(02).

Hamid, I. (2018). Urgensitas UU No. 32 Tahun 2004 terhadap Pilkada Serta Implikasinya dalam Perubahan Sosial Kemasyarakatan (Tinjauan terhadap Pilkada NTB Tahun 2008). Politea: Jurnal Politik Islam, 1(2), 169-203.

Kamim, A.B.M., Amal, I., \& Khandiq, M.R. (2018). Dilema pemetaan partisipatif wilayah masyarakat adat di Indonesia: upaya resolusi konflik agraria dan kritiknya. Prosiding Senaspolhi POLHI, 1(1),107-120.

Kushandayani, K. (2011). Studi Evaluasi Penyelenggaraan Pemerintahan Desa Berdasarkan UU No. 32 Tahun 2004 Tentang Pemerintahan Daerah. Jurnal Bhinneka Tunggal Ika (Ulasan Ilmiah Politik, Otonomi, SDA dan Pluralistik, 2(2), 67-82.

Mangku, D.G.S. (2017). Peran Border Liasion Committee (BLC) Dalam Pengelolaan Perbatasan Antara Indonesia dan Timor Leste. Perspektif, 22(2), 99-114.

Mathiyazhagan, T., \& Nandan, D. (2010). Survey research method. Media Mimansa, 4(1), 34-45.

Melawi, T.P.B.K. (2014). Evaluasi Kebijakan Pemekaran Kecamatan. Jurnal Tesis PMISUNTAN-PSIAN, 1-20.

Moore, C.W. 1987. Th e Caucus: Private Meetings that Promote Settlement. Mediation Quarterly 16: 87-101.

Moore, C.W., \& Woodrow, P.J. (2010). Handbook of global and multicultural negotiation. John Wiley \& Sons.

Oktarina, D. (2018). Analysis of Potential Region Expansion in Renah Indojati Pesisir Selatan Regency, Indonesia. Science and Environmental Journal for Postgraduate, 1(1), 43-51.

Rachayu, K. (2019). Efektivitas Otonomi Daerah Dalam Membangun Pemberdayaan Sumber Daya Manusia Pada Masyarakat Pedesaan. Sosiohumaniora, 21(1), 17-21.
Ristanti, Y.D., \& Handoyo, E. (2017). Undangundang otonomi daerah dan pembangunan ekonomi daerah. Jurnal RAK (Riset Akuntansi Keuangan), 2(1), 115-122.

Rohmahwati, P. (2016). Project-based learning to raise students' speaking ability: its' effect and implementation (a mix method research in speaking II subject at STAIN Ponorogo). Kodifikasia, 9(1), 199-222.

Rothenberg, A.D., Bazzi, S., Nataraj, S., \& Chari, A.V. (2017). When Regional Policies Fail: An Evaluation of Indonesia's Integrated Economic Development Zones. Working Paper, 1-45.

Rusli, B. (2003). Mencermati Penerapan Kebijakan Otonomi Daerah. Sosiohumaniora, 5(3), 179.

Rustandi, R. (2017). Kajian Teoritis Fungsi Pemerintah Daerah Dan Dewan Perwakilan Rakyat Daerah Dalam Pembentukan Peraturan Daerah Menurut Undang-Undang Nomor 23 Tahun 2014Tentang Pemerintahan Daerah Sebagaimana Telah Diubah Dengan Undang-Undang Nomor 9 Tahun 2015. Jurnal Surya Kencana Dua: Dinamika Masalah Hukum dan Keadilan, 4(1), 35-53.

Sahyana, Y. (2019). Penyelesaian Sengketa Batas Daerah Menggunakan Pendekatan Regulasi. Jurnal Konstituen, 1(1), 51-64.

Sulistiowati, R. (2014). Implementasi Desentralisasi dan Otonomi Daerah pada Daerah Otonomi Baru (DOB). Sosiohumaniora, 16(3), 270282.

Teddlie, C., \& Tashakkori, A. (2011). Mixed methods research. The Sage handbook of qualitative research, 4, 285-300.

Vaismoradi, M., Turunen, H., \& Bondas, T. (2013). Content analysis and thematic analysis: Implications for conducting a qualitative descriptive study. Nursing \& health sciences, 15(3), 398-405.

Zein, Y.A. (2016). Politik Hukum Pengelolaan Wilayah Perbatasan Berbasis Pemenuhan Hak Konstitusional Warga Negara. Jurnal Hukum IUS QUIA IUSTUM, 23(1), 97-122. 